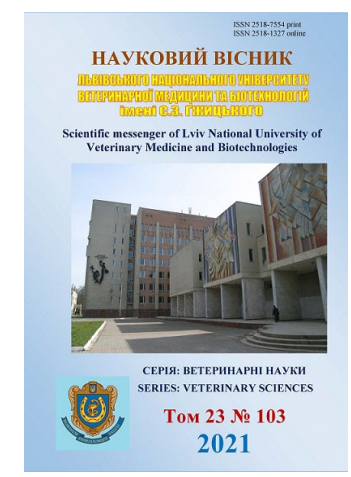

\author{
Науковий вісник Дьвівського національного університету \\ ветеринарної медицини та біотехнологій імені С.3. Гжицького. \\ Серія: Ветеринарні науки \\ Scientific Messenger of Lviv National University \\ of Veterinary Medicine and Biotechnologies. \\ Series: Veterinary sciences
}

\title{
Morphological and morphometrical characteristics of cattle heart structure
}

\author{
L. P. Goralskyi, M. R. Ragulya, I. M. Sokulskyi, N. L. Kolesnik, I. Y. Goralska
}

Polissia national university, Zhytomyr, Ukraine

Article info

Received 02.08.2021 Received in revised form 02.09 .2021

Accepted 03.09.2021

Polissia national university, Staryj Boulevard, 7, Zhytomyr, 10002, Ukraine. Tel.: +38-097-785-73-20 E-mail: sokulskiy_1979@ukr.net
Goralskyi, L. P., Ragulya, M. R., Sokulskyi, I. M., Kolesnik, N. L., \& Goralska, I. Y. (2021). Morphological and morphometrical characteristics of cattle heart structure. Scientific Messenger of Lviv National University of Veterinary Medicine and Biotechnologies. Series: Veterinary sciences, 23(103), 145-151. doi: 10.32718/nvlvet10320

The paper presents the results of macro- and microscopic structure of cattle heart on the organ-, tissueand cell levels. The samples of the selected material $(n=5)$ were preserved in a $10-12 \%$ water solution of neutral formaline with its further charging into wax. Histologic sections not more than $10 \mathrm{mkm}$ were made from wax blocks by using a sliding microtome MC-2. Hematoxilin- and eosin staining of histological sections by Heydengine technique was used for studying cell morphology, carrying out morphometrical studies and for receiving review samples. Histoarchitecture of the structural parts of the heart (ventricle and auricle) and their morphometrical parameters were studied on the histological preparations using the light microscopy technique. The experimantal part of the scientific research was carried out in compliance with the requirements of "European Convention for the Protection of Vertebrate Animals used for Experimantal and other Scientific Purposes" (Strussburg, 1986). The cattle heart is located in a thorax between two lungs, in front of a diaphragm and shifted left. In the $3^{\text {rd }}-4^{\text {th }}$ rib region the heart adjacents to a thoracic wall. The heart apex is in the $5^{\text {th }}$ rib region. The absolute weight of a cattle heart equals $2143.27 \pm 38.76 \mathrm{~g}$, the relative weight equals $-0.43 \pm 0.006 \%$. The net weight of the heart without the epicardial fat equals $1926.12 \pm 31.12 \mathrm{~g}$. Herewith, the weight of the aortic ventricle equals $978.54 \pm 19.52 \mathrm{~g}$, the weight of the pulmonic ventricle equals $554.17 \pm 14.21 \mathrm{~g}$, the weight of both ventricles equals $1539.08 \pm 49.74 \mathrm{~g}$. The auricles weight was the least and equaled $397.18 \pm 11.21 \mathrm{~g}$. The ratio of the ventricle weight of the heart to its net weight equals 1:0.2, and the ratio of the weight of the auricle myocard to the weight of the ventricle myocard equals 1:0.26. The heart height equaled $23.08 \pm 0.11 \mathrm{~cm}$, width $-13.9 \pm 0.18 \mathrm{~cm}$ and the circumference $-38.08 \pm 0.9 \mathrm{~cm}$. According to the analysis of such liniar measurements, the cattle heart in the animals of the experimental group is characterized as that of an enlarged-and short form. The heart wall consists of three sacs-endocardium, myocard and epicardium. The dominating weight of the heart wall is in a muscular layer (myocard), which consists of transversus stripe muscular fibers which are formed on the basis of mononuclear cells - cardiomyocytes which are interlinked into muscular fibers. According to the cytometric analysis of cardiomyocytes, their largest volume - $\left(11225.73 \pm 824.42 \mathrm{mkm}^{3}\right)$ is observed in the aortic ventricle, smaller $-(7963.60 \pm$ $\left.627.09 \mathrm{mkm}^{3}\right)$ - in a pulmonic ventricle and the smallest - $\left(5361.60 \pm 583.91 \mathrm{mkm}^{3}\right)$ in the auricle cardiomyocytes. Herewith, the volumes of cardiomyocytes nuclei in an aortic ventricle $\left(124.55 \pm 7.99 \mathrm{mkm}^{3}\right.$ and in a pulmonuc ventricle $\left(121.67 \pm 7.02 \mathrm{mkm}^{3}\right)$ are nearly the same, and in the auricle cardiomyocytes the nuclei volume is significantly smaller and it equals $101.05 \pm 6.04 \mathrm{mkm}^{3}$ respectively. Such morphometrical parameters of cardiomyocytes and their nuclei are evidenced in their nuclei-cytoplasmatic ratio, which is the smallest in the cardiomyocytes of an aortic ventricle $-0.0113 \pm 0.0068$, somewhat larger in a pulmonic ventricle $0.0156 \pm 0.0054$ and the largest $-0.0234 \pm 0.0058$ in the auricle cardiomyocytes, that is connected with the special properties of the muscular tissue of a myocard which is capable of spontaneous rythmic beatings depending on their morphofunctional load: the ventricles pump the blood from the heart to the body performing the gratest load (the aortic ventricle acts a s a pump, and the pulmonic ventricle acts as a container), the auricles receive the blood which returns to the heart from the animal body, performing somewhat smaller load.

Key words: cattle, heart, myocard, ventricles, auricle, cardiomyocytes, microscopic structure, morphometry. 


\title{
Морфологічні та морфометричні особливості будови серця великої рогатої худоби
}

\author{
Л. П. Горальський, М. Р. Рагуля, І. М. Сокульський, Н. Л. Колеснік, І. Ю. Горальська
}

\author{
Поліський національний університет, м. Житомир, Украӥна
}

\begin{abstract}
У науковій статті подані результати макро- та мікроскопічної будови серия великої рогатої худоби на органному, тканинному та клітинному рівнях. Для їх проведення шматочки відібраного матеріалу $(n=5)$ піддавали фіксації у 10-12 \%-ому водному розчині нейтрального формаліну з наступною заливкою його у парафін. 3 парафінових блоків виготовляли гістологічні зрізи на санному мікротомі МС-2 завтовшки не більше 10 мкм. Для дослідження морфології клітини, проведення морфометричних досліджень та для отримання оглядових препаратів застосовували фарбування гістозрізів гематоксиліном і еозином та за методом Гейденгайна. Гістоархітектоніку структурних частин серия (шлуночки, передсердя) та їх морфометричні параметри досліджували на гістологічних препаратах методом світлової мікроскопї. Уся експериментальна частина наукового дослідження була проведена згідно з вимогами міжнародних принципів “Свропейської конвенції щзодо захисту хребетних тварин, які використовують в експерименті та інших наукових иілях” (Страсбург, 1986 р.). Серие великої рогатої худоби знаходиться у грудній порожнині між обома легенями, спереду діафрагми та змімене дещзо вліво. У ділянці 3-4-го ребра серие прилягає до лівої грудної стінки. Верхівка серия лежить у ділянџі 5-го реберного хрящуа. Абсолютна маса серия у ВРХ становить $2143,27 \pm 38,76$ г, відносна маса -

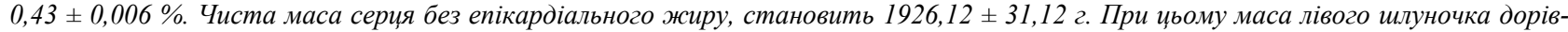

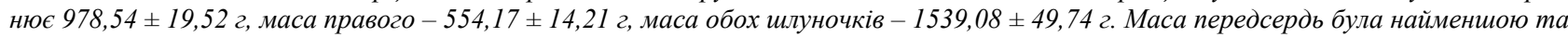

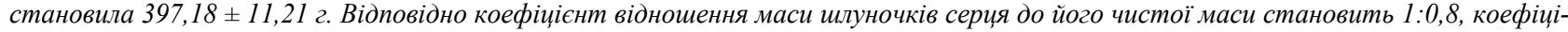
єнт відношення маси передсердь до чистої маси серця - 1:0,2, а коефіцієнт відношення маси міокарду передсердь до маси міокарду шлуночків становить 1:0,26. Висота серия становила 23,08 \pm 0,11 см, иирина - 13,9 0,18 см, окружність - 38,08 0,9 см. Згідно аналізу таких лінійних промірів, серце у тварин дослідної групи ВРХ характеризується як розширено-вкороченої форми. Стінка серия сформована трьома оболонками - внутрішньою (ендокард), середньою (міокард) $і$ зовнішньою (епікард). Домінуючу масу стінки серия становить м'язова оболонка - міокард, який сформований поперечнопосмугованими м'язовими волокнами, ицо побудовані із одноядерних клітин - кардіоміочитів, які з'єднані між собою у м'язові волокна вставними дисками. лівого шилночка

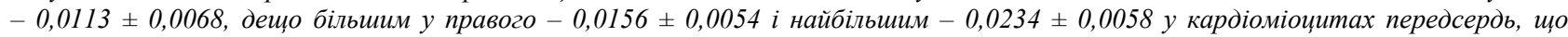
пов 'язано з особливостями м'язової тканими міокарду, здатної до спонтанних ритмічних скорочень, залежно від їх морфофункціонального навантаження: шлуночки перекачують кров від серия до тіла, виконуючи при тім найбільше навантаження (лівий шлуночок функиіонує, в основному, як насос, правий - як об'ємний), передсердя отримують кров, щзо повертається до серия від тіла тварин, виконуючи при тім менше навантаження.
\end{abstract}

Ключові слова: велика рогата худоба, серие, міокард, шлуночки, передсердя, кардіоміоцити, мікроскопічна будова, морфометрія.

\section{Вступ}

Основним напрямком сучасного стану та перспективами успішного розвитку галузі тваринництва та ветеринарної медицини $є$ підвищення продуктивних якостей тварин та профілактика захворювань заразної та незаразної патології (Gutyj et al., 2017; Kulyaba et al., 2019; Grymak et al., 2020; Roman et al., 2020). Тому, поряд із організаційно-господарськими заходами, необхідно проводити поглиблене дослідження організму продуктивних тварин в цілому та морфології органів і систем зокрема (Stravsky et al., 2020). Впродовж останніх років, достеменне значення мають морфометричні дослідженням макро- та мікроскопічної будови органів і систем у клінічно здорових тварин, які $\epsilon$ морфологічними критеріями діагностики захворювань у людей та тварин (Dzau et al., 2006; Tatarchuk, 2011). Доведено високу ефективність морфометричної оцінки стану організму тварин на органному, тканинному та клітинному рівнях (Shevchenko et al., 2018).

Актуальним питанням є дослідження морфофункціональних особливостей серцево-судинної системи (Stakhurska \& Pryshliak, 2014), яка в організмі тварин виконує життєво-важливі функції та має пізнавальне значення і $є$ основою для клінічної ветеринарної медицини (Vansiatskaia \& Kyrpaneva, 2014).
Серцево-судинна система, до складу якої входить серце та кровоносні судини, є однією із інтегруючих систем організму, що відіграє важливу роль у підтриманні його гомеостазу і сприяє реалізації функцій нервової, ендокринної системи та органів імунного захисту (Zhurenko et al., 2018). Вона регулює кровопостачання органів, тиск крові, забезпечує відтік лімфи органів і транспорт іiі у вени (Khomych et al., 2020). Серцево-судинна система забезпечує обмін речовин, має важливе значення у регуляції функцій усіх органів та систем організму, беручи участь у забезпеченні дихальної, трофічної, екскреторних функцій і разом із нервовою системою, поєднує між собою всі органи та системи організму у єдине ціле (Ciszek et al., 2007). Завдяки їй $з$ кров'ю до тканин органів надходить Оксисен, поживні речовини і гормони та виводиться із них продукти обміну речовин. Центральним органом серцево-судинної системи є серце, яке завдяки постійному скороченню кардіоміоцитів міокарду, здійснює течію крові по замкнутій системі кровоносних судин (Krešáková et al., 2015).

Тому, нами було досліджено макро- та мікроскопічну будову серця та проведено його морфометричну оцінку морфологічних структур у великої рогатої худоби, показники яких є морфологічними критеріями фізіологічних та патологічних змін у серцевосудинній системі і можуть використовуватись при 
діагностиці захворювань різноманітного генезу (Slabyi, 2017).

\section{Матеріал і методи досліджень}

Робота $є$ фрагментом комплексної тематики кафедри анатомії і гістології факультету ветеринарної медицини Поліського національного університету: “Розвиток, морфологія та гістохімія органів тварин у нормі та при патологіï”, державний реєстраційний № $0120 \mathrm{U} 100796$.

Задля цього використовували макро- та мікроскопічні, морфометричні та статистичні методи досліджень (Horalskyi et al., 2019). Об'єктом дослідження було серце клінічно здорової статево зрілої великої рогатої худоби $(\mathrm{n}=5)$.

При проведенні досліджень дотримувались правил належної лабораторної практики GLP (1981р.), положень “Загальних етичних принципів експериментів на тваринах", ухвалених I Національним конгресом 3 біоетики (м. Київ, 2001 р.). Експериментальні дослідження були проведені згідно з вимогами міжнародних принципів “Європейської конвенції щодо захисту хребетних тварин, які використовують в експерименті та інших наукових цілях" (Страсбург, 1986 р.), “Правилами проведення робіт 3 використанням експериментальних тварин”, затверджених наказом MO3 № 281 від 1 листопада 2000 р. “Про заходи щодо подальшого удосконалення організаційних форм роботи 3 використанням експериментальних тварин" та відповідного ЗУ "Про захист тварин від жорстокого поводження” (№ 3447-IV від 21.02.2006 р., м. Київ) (Yablonska, 2019).

Серце відпрепаровували з грудної клітки тварин разом із перикардом. Його розріз проводили після виміру макрометричних параметрів, після чого проводили поздовжний розтин шлуночків через відповідні атріовентрикулярні отвори.

Для проведення мікроскопічних досліджень застосовували загальноприйняті методи фіксації та виготовлення гістозрізів (Horalskyi et al., 2019). Для цього шматочки матеріалу фіксували у 12 \%-ому охолодженому водному розчині нейтрального формаліну впродовж 24 год і більше, з наступною заливкою його у парафін за схемами, запропонованими у посібнику Л. П. Горальського, В. Т. Хомича, О. І. Кононського (Horalskyi et al., 2019). Парафінові зрізи виготовляли на санному мікротомі MC-2, їх товщина не перевищувала 10-12 мкм.

Для дослідження мікроскопічної будови серця, гістозрізи, після їх депарафінації, фарбували гематоксиліном та еозином та за методом Гейденгайна. Зафарбовані гістозрізи використовували для отримання оглядових препаратів та проведення гістометричних досліджень. Гістометричні дослідження структурних елементів (виміри довжини та ширини кардіоміоцитів, об'єму їх ядер) здійснювали при світловій мікроскопії за допомогою мікроскопів “Micros" та МБС-10 3 постійною довжиною тубуса, згідно з рекомендаціями викладеними у посібнику (Horalskyi et al., 2019).

Об'єм кардіоміоцитів визначали за формулою: $\mathrm{V}=\Pi \times \mathrm{A} \times(\mathrm{B} / 2)^{2}$, де:

$\mathrm{V}$ - об'єм кардіоміоцита;

$\Pi-3,14$;

А - довжина кардіоміоцита;

В - ширина кардіоміоцита.

Фотографування гістологічних препаратів здійснювали відеокамерою CAM V-200, вмонтованою у мікроскоп.

Морфологічні терміни структурних частин серця подано згідно з Міжнародною ветеринарною гістологічною номенклатурою (Термінологічний словник) (2019) та Міжнародною ветеринарною анатомічною номенклатурою (2012).

Цифровий матеріал обробляли за допомогою варіаційно-статистичних методів на персональному комп'ютері 3 використанням ліцензованої програми Statystica 6.0 для Windows XP.

\section{Результати та їх обговорення}

Серце великої рогатої худоби розташоване у грудній порожнині між обома легенями, попереду діафрагми та зміщене вліво. У ділянці 3-4 - го ребра серце прилягає до лівої грудної стінки. Верхівка серця лежить у ділянці 5-го реберного хряща. Його абсолютна маса становить $2143,27 \pm 38,76$ г, відносна маса дорівнює $0,43 \pm 0,006 \%$.

Серце великої рогатої худоби конусоподібної форми (рис. 1, 2). Його основа має дорсальний, а верхівка - вентральний напрямки. Внутрішньо, порожнина серця перегородкою поділена на ліву і праву половини, які розділені відповідно на передсердя та шлуночки. Передсердя та шлуночки, сполучаються між собою, передсердно-шлуночковим отвором. Передсердя, як правило знаходяться на самій основі серця. Ззовні передсердя розмежовані від шлуночків поперечною вінцевою борозною, яка добре візуалізується

На поверхні серця як у людини, так і тварин добре поперечно розташована вінцева борозна

Праве та ліве передсердя в основі серця формують мішкоподібні випинання - праве та ліве серцеві вушка, які спрямовані у краніальному напрямку та розміщені праворуч та ліворуч, відповідно від стовбура легеневих артерій та аорти. Шлуночки серця займають домінуючу частину серця та ззовні вони відділені між собою міжшлуночковими підпазушною та біляконусною борознами, які з'єднуються на краніальній поверхні серця, не досягаючи верхівки серця та відділяють правий шлуночок від лівого. Верхівка серця у великої рогатої худоби відноситься до лівого шлуночка. Лівий шлуночок озташований зліва та каудально, правий шлуночок знаходиться краніально та справа. Подібно розташовані і міжшлуночкові борозни (підпазушна - аудально, біляконусна - краніально). 


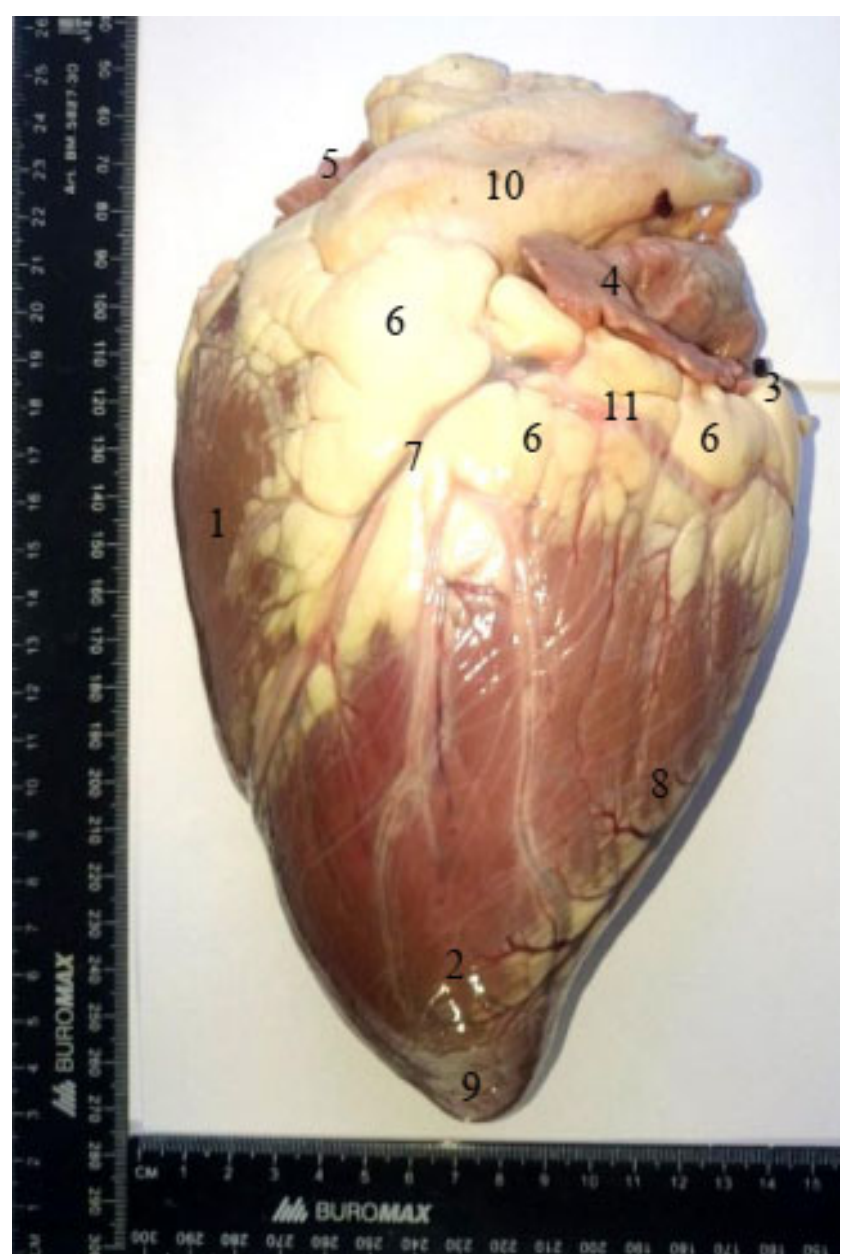

Рис. 1. Макроскопічна будова серця великої рогатої худоби, (ліва сторона): 1 - правий шлуночок; 2 - лівій шлуночок; 3 - ліве передсердя; 4 - ліве вушко; 5 - праве вушко; 6 - субепікардіальний жир;

7 - біляконусна міжшлуночкова борозна; 8 - середня міжшлуночкова борозна; 9 - верхівка серця;

10 - легеневий стовбур; 11 - ліва непарна вена. Фото 3 макропрепарата

Чиста маса серця, без епікардіального жиру, у ВРХ становить $1926,12 \pm 31,12$ г. При цьому висота серця дорівнює 23,08 $\pm 0,11 \mathrm{~cm}$, ширина серця $13,9 \pm 0,18 \mathrm{~cm}$ відповідно, окружність $-38,08 \pm 0,9$ см. Зі співставленням даних літератури (Vansiatskaia \& Kyrpaneva, 2014) та аналізу проведених нами лінійних промірів, серце тварин дослідної групи має розширеновкорочену форму.

Згідно органометричних досліджень маса лівого шлуночка серця становить 978,54 \pm 19,52 г, масса правого шлуночка $-554,17 \pm 14,21$ г. Середня маса обох шлуночків (правого та лівого) дорівнює 1539,08 \pm 49,74 г. При цьому маса передсердь становить 397,18 \pm 11,21 г. Відповідно коефіцієнт відношення маси шлуночків серця до його чистої (без епікардіального жиру) маси становить 1:0,8, коефіцієнт відношення маси передсердь до чистої маси серця відповідно - 1:0,2, а коефіцієнт відношення маси міокарду передсердь до маси міокарду шлуночків становить 1:0,26. При тім товщина стінки шлуночків серця перебуває у тісному взаємозв'язку з масою самих шлуночків, лівого та пра-

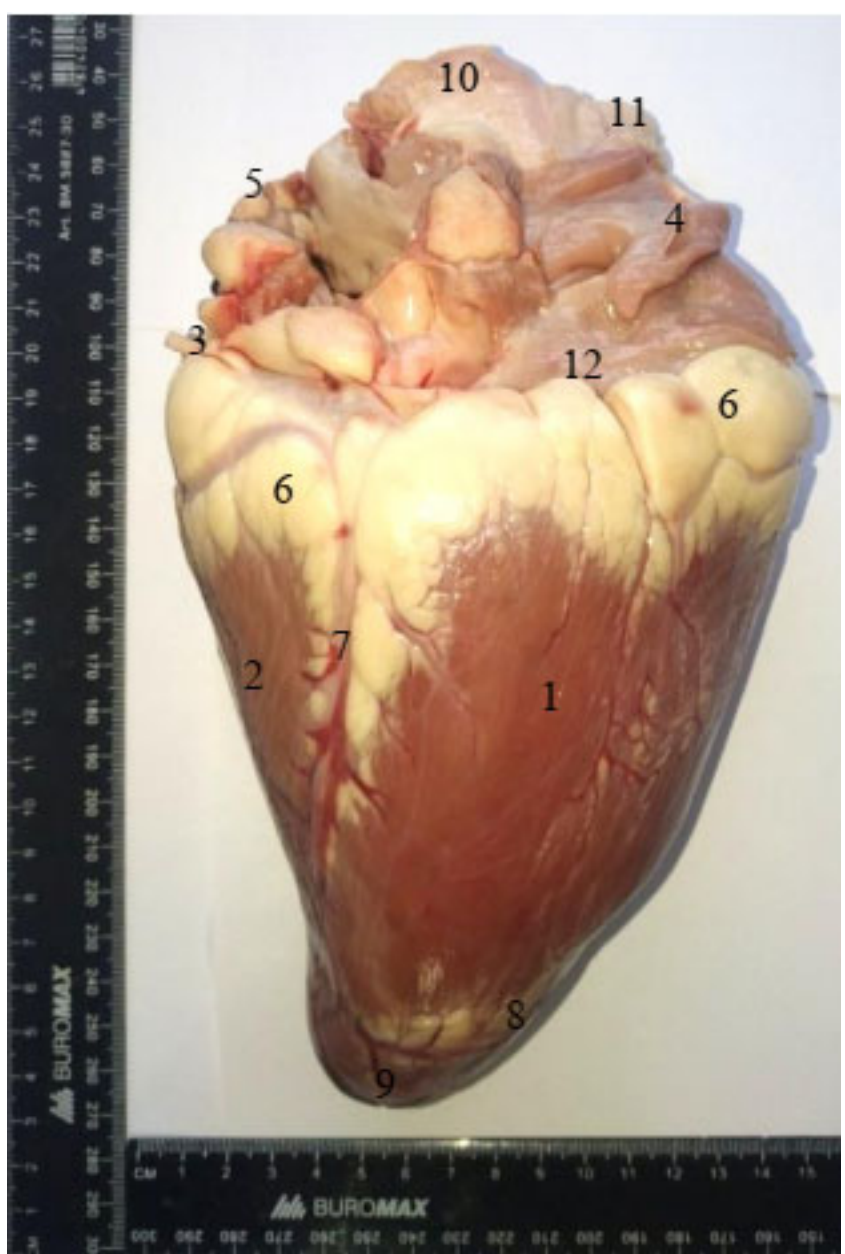

Рис. 2. Макроскопічна будова серця великої рогатої худоби, (права сторона): 1 - правий шлуночок;

2 - лівій шлуночок; 3 - ліве передсердя; 4 - праве вушко; 5 - легеневі вени; 6 - субепікардіальний жир; 7 - підпазушна міжшлуночкова борозна; 8 - біляконусна міжшлуночкова борозна; 9 - верхівка серця; 10 - аорта; 11 - плечоголовний стовбур; 12 - праве передсердя. Фото з макропрепарата

вого. Так, товщина стінки лівого шлуночка є більшою, ніж правого, у 1,98 рази $(\mathrm{P} \leq 0,01)$ і становить $36,54 \pm$ 0,64 мм, а правого $18,46 \pm 0,52$ мм. Товщина стінки передсердь дорівнює 7,69 \pm 0,23 мм.

Стінка серця сформована трьома оболонками внутрішньою - ендокард, середньою - міокард і зовнішньою - епікард. Домінуючу масу стінки серця формує м'язова оболонка - міокард.

Міокард передсердь сформований двома шарами зовнішнім (загальним $є$ для обох передсердь) та глибоким. М'язові волокна зовнішнього шару міокарду прямують у поперечному напрямі від одного вушка до іншого. Глибокий шар міокарду у правому і лівому передсерді має поздовжні напрямки. Водночас у ділянці венозних отворів виявляються сформовані колові пучки волокон.

Стінки шлуночків міокарду товстіші за стінки його передсердь, що пов'язано з їх функціональною діяльністю. При цьому, мікард шлуночків сформований п'ятьма шарами: зовнішнім та внутрішнім, м'язові волокна яких мають косопоздовжній напрямок, потім 
- зовнішнім та внутрішнім більш глибокими шарами та найглибшим шаром, волокна яких мають напрямок подібний до вісімки.

Мікроскопічна будова міокарду серця сформована поперечнопосмугованими м'язовими волокнами, які побудовані із одноядерних клітин - кардіоміоцитів, які з'єднані між собою у м'язові волокна вставними дисками (рис. 3). Під світловим мікроскопом, зафарбованих гістопрепаратів за методом Гейденгайна, кардіоміоцити мають вигляд темних поперечних смужок. У них чітко диференціюється сарколема, міофібрили та ядра, які знаходяться у центральній частині клітин.

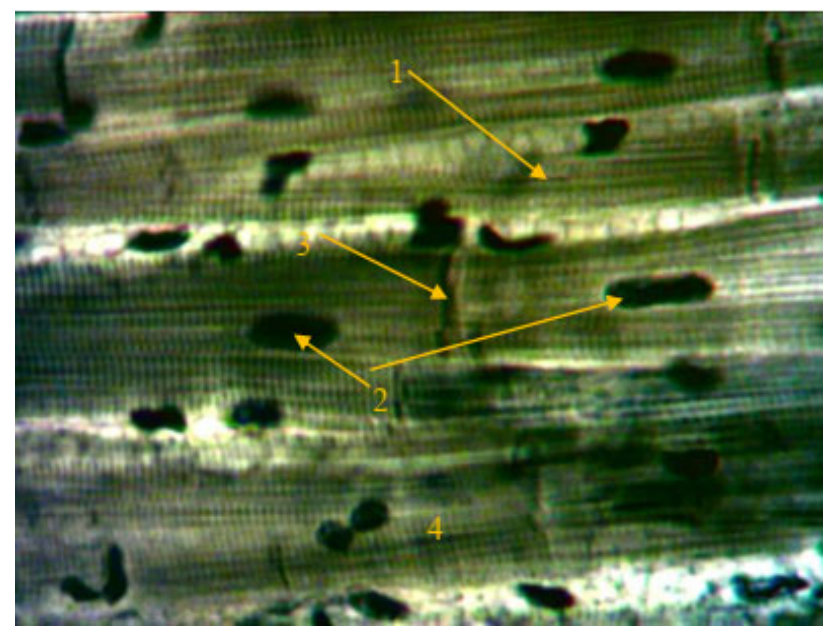

Рис. 3. Мікроскопічна будова міокарда лівого шлуночка великої рогатої худоби: 1 - кардіоміоцити;

2 - ядра кардіоміоцитів; 3 - вставні диски;

4 - поперечня посмугованість. Фарбування за методом Гейденгайна. Х 600.

М'язові волокна між собою, з'єднуються у єдине ціле, за допомогою анастомозів, формуючи таким чином сіткоподібну структуру (рис. 4). Між м'язовими волокнами виявляються прошарки міжм'язової сполучної тканини, де знаходяться кровоносні та лімфатичні судини.

У м'язових волокнах, чітко диференціюються наявні поздовжня (внаслідок міофібрил) та поперечна (внаслідок білків актину та міозину) посмугованість. При тім, міофібрили, що щільно розташовані одна біля одної, розміщені ближче до периферії волокон та iз одного волокна по анастомозам потрапляють в інші. За відносно незначної кількості міофібрил, поздовжня посмугованість кардіоміоцитів виражена чітко, а поперечна - відносно слабко. Окрім того, кардіоміоцити значно більші за своєю шириною, погано сприймають забарвлення, їх поперечна посмугованість слабко виражена, а міофібрили у таких випадках набувають витонченої форми.

Кардіоміоцити малої ширини, на поперечному зрізі мають овальний вигляд, міофібрили у них розташовані більш щільно.

У центрі кардіоміоцитів міститься одне, рідко два ядра, овальної або ж видовженої форми, які розміщені нерівномірно. Ядерний хроматин у вигляді малих або ж крупніших зерен виявляється по всьому периметру каріоплазми.

Аналіз результатів мікроскопічних досліджень свідчить, що гістоархітектоніка міокарда шлуночків та передсердь серця має подібну будову. Водночас, враховуючи доцільність застосування гістометричних методів досліджень (Hushchyn, 2021), які дають можливість встановити навіть несуттєві зміни мікроскопічної будови на тканинному та клітинному рівнях, які неможливо помітити за звичайних гістологічних досліджень, нами було проведено цитометрію скоротливих кардіоміоцитів міокарду серця, його шлуночків та передсердь.

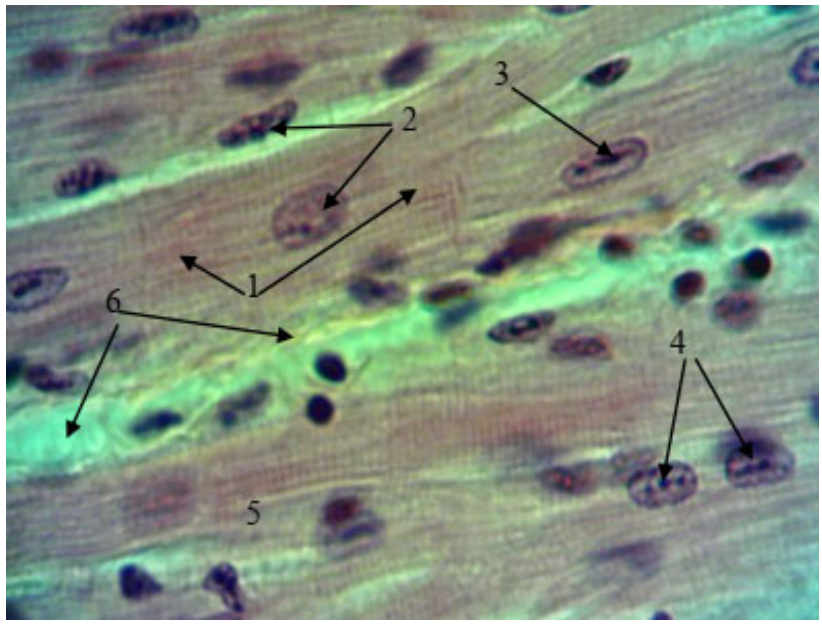

Рис. 4. Мікроскопічна будова міокарда правого шлуночка великої рогатої худоби: 1 - кардіоміоцити;

2 - ядра кардіоміоцитів; 3 - ядерця; 4 - ядерний хроматин; 5 - анастомози; 6 - міжм'язова сполучна тканина. Гематоксилін та еозин. Х 600.

Так, за результатами наших досліджень, кардіоміоцити, які формують м'язові волокна, залежно від їх морфотопографії (лівий, правий шлуночки, передсердя) мають неоднозначні морфометричні параметри. Проведений нами детальний аналіз цитометричних досліджень мікроструктур міокарда засвідчує, що кількісні показники кардіоміоцитів у лівому шлуночку серця більші, ніж такі у правому. Так, у ВРХ довжина кардіоміоцитів лівого шлуночка у 1,16 рази більша ніж правого і становить - 72,02 $\pm 1,08$ мкм, ширина кардіоміоцитів, відповідно у 1,1 рази і дорівнює 14,06 $\pm 0,41$ мкм. Аналогічні зміни виявлено нами і при морфометричному дослідженні об'ємів кардіоміоцитів та їх ядер. Так, найбільший об'єм кардіоміоцитів спостерігається у лівому шлуночку $11225,73 \pm 824,42$ мкм³ $^{3}$ У правому шлуночку серця, такий показник менший у 1,4 рази і становить відповідно 7963,60 $\pm 627,09$ мкм³. Аналогічні зміни спостерігаються і при визначенні об'єму ядер кардіоміоцитів, який більшим був у ядрах кардіоміоцитів лівого шлуночка - 124,55 \pm 7,99 мкм ${ }^{3}$ і дещо меншим у правому шлуночку - 121,67 \pm 7,02 мкм³ $^{3}$ А від так, для кардіоміоцитів шлуночків було різне для них ядерноцитоплазматичне відношення, яке найменше виявлялось у кардіоміоцитів лівого шлуночка $(0,0113 \pm$ 0,0068) i значно більше у кардіоміоцитів правого 
шлуночка $(0,0156 \pm 0,0054)$, що вказувало на їх морфофункціональну активність. Це не випадковість, а реальна та об'єктивна характеристика різниці у діяльності шлуночків, оскільки лівий функціонує в основному як насос, а правий - як об'ємний (Misfeld \& Sievers, 2007). Тому, збільшення цитометричних показників кардіоміоцитів міокарду лівого шлуночка, порівняно з правим шлуночком, пов'язані з функціональним особливостями м'язової тканими мікарду, здатної до спонтанних ритмічних скорочень, сприяючи руху крові по судинам. При тім, кардіоміоцити лівого шлуночка виконують більше навантаження, сприяючи руху крові по судинам великого кола кровообігу, відповідно кардіоміоцити правого шлуночка
- менше навантаження, сприяючи руху крові по судинам малого кола кровообігу.

Найменші морфометричні параметри (довжина, ширина кардіоміоцитів, об'єм кардіоміоцитів, об'єм їх ядер) були у кардіоміоцитах передсердь, в яких ЯЦВ було найбільшим i дорівнювало відповідно $0,0234 \pm 0,0058$ (табл. 1), що свідчило про менше морфофункціональне навантаження кардіоміоцитів передсердь порівняно з кардіоміоцитами шлуночків, адже найбільш морфофункціонально активними та зрілими соматичними клітинами $є$ ті, для яких характерний низький індекс ЯЦВ i, навпаки, клітини з високим ЯЦМ $є$ менш функціонально активними (Horalskyi et al., 2020).

\section{Таблиця 1}

Гістометричні показники кардіоміоцитів великої рогатої худоби $(\mathrm{M} \pm \mathrm{m}, \mathrm{n}=5)$

\begin{tabular}{lllccl}
\hline \multicolumn{1}{c}{ Показники } & $\begin{array}{c}\text { Довжина кардіо- } \\
\text { міоцитів (мкм) }\end{array}$ & $\begin{array}{c}\text { Ширина кардіо- } \\
\text { міоцитів (мкм) }\end{array}$ & $\begin{array}{c}\text { Об'єм кардіоміо- } \\
\left.\text { цитів (мкм }{ }^{3}\right)\end{array}$ & $\begin{array}{c}\text { Об’єм ядер карді- } \\
\left.\text { оміоцитів (мкм }{ }^{3}\right)\end{array}$ & \multicolumn{2}{c}{ ЯцВ } \\
\hline Лівий шлуночок & $72,02 \pm 1,08$ & $14,06 \pm 0,41$ & $11225,73 \pm 824,42$ & $124,55 \pm 7,99$ & $0,0113 \pm 0,0068$ \\
Правий шлуночок & $62,07 \pm 1,23$ & $12,79 \pm 0,38$ & $7963,60 \pm 627,09 *$ & $121,67 \pm 7,02$ & $0,0156 \pm 0,0054^{*}$ \\
Передсердя & $56,08 \pm 1,37^{*}$ & $10,02 \pm 0,46^{*}$ & $5361,60 \pm 583,91^{* *}$ & $101,05 \pm 6,04^{*}$ & $0,0234 \pm 0,0058^{* *}$ \\
\hline
\end{tabular}

Примітка: * - $\mathrm{P} \leq 0,05 ;$ ** - $\mathrm{P} \leq 0,01 ; * * *-\mathrm{P} \leq 0,001$ по відношенню до лівого

Такі неоднозначні цитометричні параметри кардіоміоцитів шлуночків та передсердь ми пов'язуємо 3 морфофункціональною діяльністю роботи серця: передсердя отримують кров, що повертається до серця від тіла тварин, а шлуночки перекачують кров від серця до тіла, виконуючи при тім найбільше навантаження.

\section{Висновки}

1. Серце великої рогатої худоби в цілому та його морфологічні структури шлуночки та передсердя мають подібну морфологічну будову, але різниться певними морфометричними параметрами, залежно від ix морфофункціонального навантаження: шлуночки перекачують кров від серця до тіла, виконуючи при тім найбільше навантаження (лівий шлуночок функціонує, в основному, як насос, правий - як об'ємний), передсердя отримують кров, що повертається до серця від тіла тварин, виконуючи при тім менше навантаження.

2. Найбільший об'єм мають кардіоміоцити лівого шлуночка - 11225,73 $\pm 824,42$ мкм $^{3}$, менший - правого 7963,60 $\pm 627,09$ мкм ${ }^{3}$ і найменший -кардіоміоцити передсердь 5361,60 \pm 583,91 мкм³. Об'єми ядер кардіоміоцитів у лівому та правому шлуночках серця $є$ майже однаковими, відповідно 124,55 \pm 7,99 мкм ${ }^{3}$ та $121,67 \pm 7,02$ мкм $^{3}$, у кардіоміоцитах передсердь такий показник значно менший і дорівнює відповідно101,05 $\pm 6,04$ мкм $^{3}$.

3. Ядерно-цитоплазматичне відношення найменшим $є$ у кардіоміоцитах лівого шлуночка $(0,0113 \pm$ 0,0068), дещо більшим - у кардіоміоцитах правого шлуночка $(0,0156 \pm 0,0054)$ і найбільшим $(0,0234 \pm$ $0,0058)$ - у кардіоміоцитах передсердь, що пов'язано 3 особливостями м'язової тканими міокарду, здатної до спонтанних ритмічних скорочень.

Перспективи подальших досліджень направленні на проведення ультрамікроскопічного дослідження структурних частин серця (шлуночки, передсердя) у свійських тварин.

\section{Відомості про конфлікт інтересів}

Автори стверджують про відсутність конфлікту інтересів.

\section{References}

Ciszek, B., Skubiszewska, D., \& Ratajska, A. (2007). The anatomy of the cardiac veins in mice. J Anat, 211(1), 53-63. doi: 10.1111/j.1469-7580.2007.00753.x.

Dzau, V. J., Antman, E. M., Black, H. R. et al. (2006). The cardiovascular disease continuum validated: clinical evidence of improved patient outcomes: part I: Pathophysiology and clinical trial evidence (risk factors through stable coronary artery disease). Circulation, 114(25), 2850 2870. doi: 10.1161/CIRCULATIONAHA.106.655688.

Grymak, Y., Skoromna, O., Stadnytska, O., Sobolev, O., Gutyj, B., Shalovylo, S., Hachak, Y., Grabovska, O., Bushueva, I., Denys, G., Hudyma, V., Pakholkiv, N., Jarochovich, I., Nahirniak, T., Pavliv, O., Farionik, T., \& Bratyuk, V. (2020). Influence of "Thireomagnile" and "Thyrioton" preparations on the antioxidant status of pregnant cows. Ukrainian Journal of Ecology, 10(1), 122-126. doi: 10.15421/2020_19.

Gutyj, B., Grymak, Y., Drach, M., Bilyk, O., Matsjuk, O., Magrelo, N., Zmiya, M., \& Katsaraba, O. (2017). The impact of endogenous intoxication on biochemical indicators of blood of pregnant cows. Regulatory Mechanisms in Biosystems, 8(3), 438-443. doi: $10.15421 / 021768$. 
Horalskyi, L. P., Khomych, V. T., \& Kononskyi O. I. (2019) Osnovy histolohichnoi tekhniky i morfofunktsionalni metody doslidzhennia u normi ta pry patolohii [Fundamentals of histological technique and morphofunctional research methods in normal and pathological conditions] Polissia, Zhytomyr (in Ukrainian).

Horalskyi, L. P., Kolesnik, N. L., Sokulskiy, I. M., Tsekhmistrenko, S. I., Dunaievska, O. F., \& Goralska, I. Y. (2020). Morphology of spinal ganglia of different segmentary levels in the domestic dog. Regulatory Mechanisms in Biosystems, 11(4), 501-505. doi: 10.15421/022076.

Hushchyn, Ya. A. (2021). Sravnitel'naja anatomija serdca cheloveka i jeksperimental'nyh zhivotnyh. Laboratornye zhivotny dlja nauch-nyh issledovanij,1, 56-67. doi: 10.29296/2618723X-2021-01-06.

Khomych, V. T. (2020). Morfolohiia sobaky. navchalnyi posibnyk, Zhytomyr, ZhNAEU (in Ukrainian).

Krešáková, L., Purzyc, H., Schusterová, I., Fulton, B., Maloveská, M., Vdoviaková, K., Kravcová, Z., \& Boldižár, M. (2015). Variability in the cardiac venous system of Wistar rats. J Am Assoc Lab Anim Sci., 54(1), 10-16. URL: https://www.ncbi.nlm.nih.gov/ pmc/articles/PMC4311736.

Kulyaba, O., Stybel, V., Gutyj, B., Turko, I., Peleno, R., Turko, Ya., Golovach, P., Vishchur, V., Prijma, O., Mazur, I., Dutka, V., Todoriuk, V., Golub, O. Dmytriv, O., \& Oseredchuk, R. (2019). Effect of experimental fascioliasis on the protein synthesis function of cow liver. Ukrainian Journal of Ecology, 9(4), 612-615. URL: https:/www.ujecology.com/abstract/effect-of-experimentalfascioliasis-on-the-protein-synthesis-function-of-cow-liver44972.html.

Misfeld, M., \& Sievers, H. H. (2007). Heart valve macroand microstructure. Philos Trans R Soc Lond B Biol Sci, 362(1484), 1421-1436. doi: 10.1098/rstb.2007.2125.

Roman, L., Sidashova, S., Popova, I., Stepanova, N., Chornyi, V., \& Gutyj, B. (2020). Clinical symptoms of damage to the lateral surface of the tibia of dairy cows of different phenotype in the conditions of industrial dairy production. Scientific Messenger of Lviv National University of Veterinary Medicine and Biotech- nologies. Series: Veterinary sciences, 22(100), 3-10. doi: $10.32718 /$ nvlvet10001.

Shevchenko, I. V. (2018). Morfolohichni osnovy morfohenezu sertsia $\mathrm{u}$ rannomu postnatalnomu rozvytku $\mathrm{V}$ normi. Visnyk problem biolohii i medytsyny, 3(145), 45-55. doi: 10.29254/2077-42142018-3-145-340-344 (in Ukrainian).

Slabyi, O. B. (2017). Kilkisna morfolohiia hipertrofovanoho sertsia. Visnyk naukovykh doslidzhen, 4, 6-8. doi: 10.11603/2415-8798.2017.4.8169 (in Ukrainian).

Stakhurska, I. O., \& Pryshliak, A. M. (2014). Morfometrychna kharakterystyka kamer sertsia tvaryn riznoi stati. Visnyk problem biolohii i medytsyny, 1(106), 269-272 (in Ukrainian).

Stravsky, Ya. S., Boltyk, N. P., Sachuk, R. M., Serheyev, V. I., \& Rushchynska, T. M. (2020). The content of total protein and protein fractions in cows during pregnancy and their diagnostic value. Scientific Messenger of Lviv National University of Veterinary Medicine and Biotechnologies. Series: Veterinary sciences, 22(99), 198-202. doi: 10.32718/nvlvet9930.

Tatarchuk, L. V. (2011). Morfometrychnyi analiz osoblyvostei remodeliuvannia kamer sertsia pislia pulmonektomyy. Zdobutky klinichnoi ta eksperymentalnoi medytsyny, 2, 123-126 (in Ukrainian).

Vansiatskaia, V. K., \& Kyrpaneva, E. A. (2014). Morfometricheskie i anatomicheskie osobennosti stroenija serdca u krupnogo rogatogo skota, svin'i i verbljuda odnogorbogo. Sel'skoe hozjajstvo - problemy i perspektivy, 29-35 (in Russian).

Yablons'ka, O. V. (2019). Vykorystannia laboratornykh tvaryn u eksperymentakh: metod. Vkazivky. K.: Vid. centr NAU, 3-16 (in Ukrainian).

Zhurenko, O. V., Karpovskiy, V. I., Danchuk, O. V., \& Kravchenko-Dovga, Yu. V. (2018). The content of calcium and phosphorus in the blood of cows with a different tonus of the autonomic nervous system. Scientific Messenger of Lviv National University of Veterinary Medicine and Biotechnologies, 20(92), 8-12. doi: $10.32718 /$ nvlvet 9202 . 